\title{
Publisher Correction: The receptor DNGR-1 signals for phagosomal rupture to promote cross-presentation of dead-cell-associated antigens
}

Johnathan Canton, Hanna Blees, Conor M. Henry, Michael D. Buck (D), Oliver Schulz, Neil C. Rogers (iD, Eleanor Childs, Santiago Zelenay, Hefin Rhys, Marie-Charlotte Domart, Lucy Collinson BD, Andres Alloatti, Cara J. Ellison,

Sebastian Amigorena, Venizelos Papayannopoulos, David C. Thomas, Felix Randow iD and Caetano Reis e Sousa (iD)

Correction to: Nature Immunology https://doi.org/10.1038/s41590-020-00824-x, published online 21 December 2020.

In the version of this article initially published, the affiliations for authors Cara Ellison, Venizelos Papayannopoulos, David C. Thomas and Felix Randow were incorrect. The error has been corrected in the PDF and HTML versions of the article.

Published online: 2 February 2021

https://doi.org/10.1038/s41590-021-00885-6

(c) Springer Nature America, Inc. 2021 